堆積学研究, 59号, 55-61, 2004

J.Sed.Soc.Japan, No. 59，55-61， 2004

\title{
堆積学を拓いた人々（7） 一級化層理から混濁流学説への発展一
}

岡田 博有*

\author{
Founders of sedimentology (7) \\ - From graded bedding to the turbidity current theory -
}

\section{Hakuyu Okada*}

\section{まえがき}

ここでは堆積学のみならず地質学, 広く地球科学 の発展に著しい貢献をすることになる級化層理 (graded bedding) の現象に初めて注目した Edward Battersby Bailey とその重要性を実験によっ て実証し, 混濁流学説を確立した Philip Henry Kuenen に焦点を当てる（岡田，2002 も参照されたい）.

\section{Edward Battersby Bailey (1881-1965)}

Edward Battersby Bailey（エドワード・バター スビ・ベイリー）（図 19）は地質調査で堆積構造の 重要性に注目して初めてその基本は級化層理 (graded bedding) と斜交層理 (current bedding, 現在は cross bedding の術語に代わっている）であ ることを示した（図 20）。彼は述べている, “many years to realize that graded bedding and current bedding are the distinguishing marks of two different sandstone facies, the one facies as important as the other." と (Bailey, 1930, p. 85). こ れらの堆積構造は複雑な地質構造地帯における地層 の上下判定に有効であることと，この二つの堆積形 式は共存しないことから堆積過程と堆積環境の違い を示唆するという画期的な解釈を行った（Bailey， 1910, 1936).この考えはその後の地質学の発展に極 めて大きい影響を与え, Ph. H. Kuenen による級化 層理の実験的研究, さらには混濁流学説 (turbidity current theory）の提唱となったことでよく知られ

受付 : 2004 年 5 月 24 日

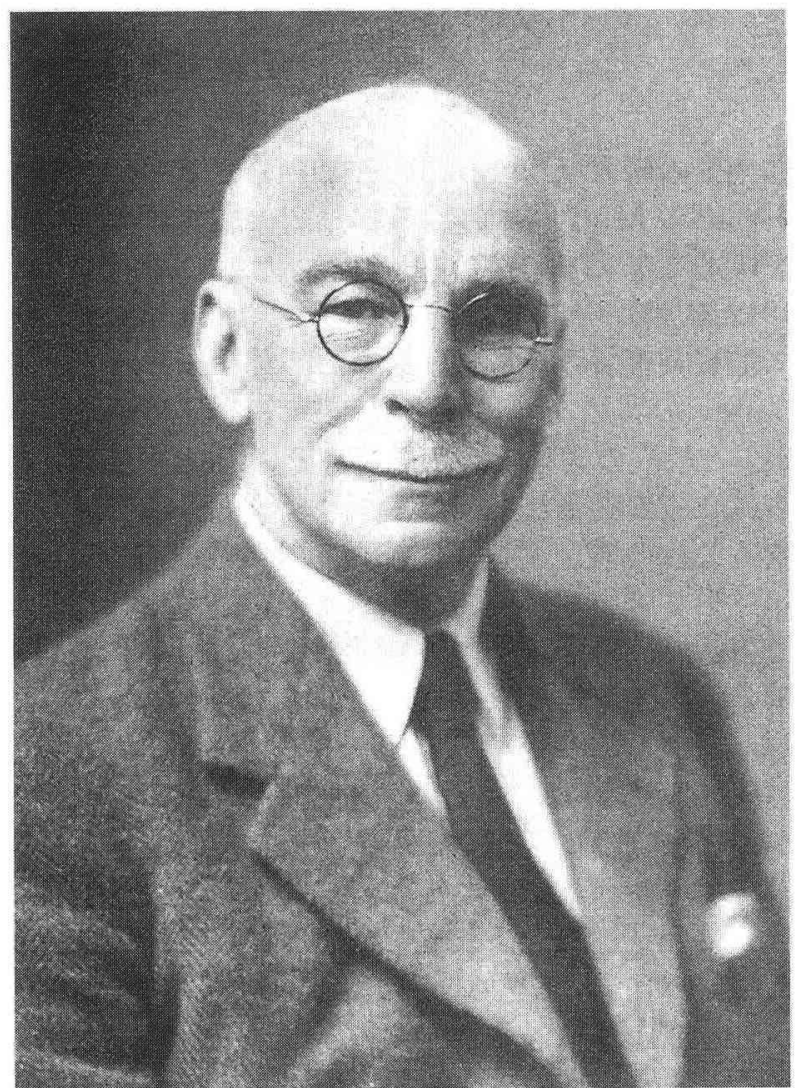

図 19 Edward Battersby Bailey (Stubblefield, 1965).

ている (次の Philip Henry Kuenen の記述を参照).

Baileyの地質学への貢献はそれだけではなかっ た。彼は野外での地質調査を天業のように愛し，ス コットランド高地の図幅調查にイギリス地質学史上 でも最高の貢献を成し遂げた，その一例が上述の堆 積現象を発見する基になった Ballachulish 横臥褶 


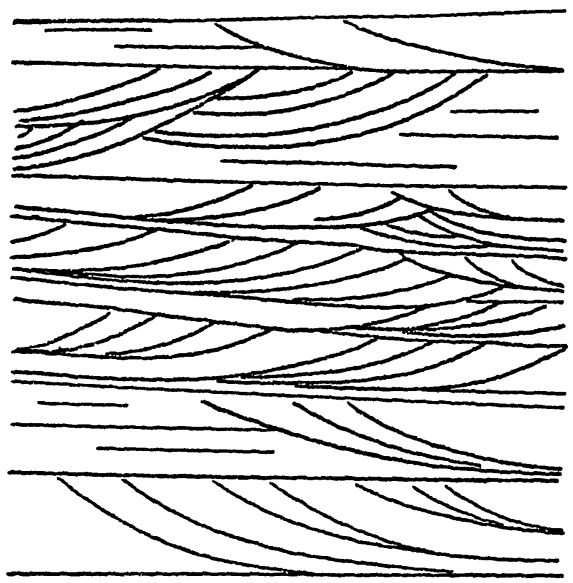

Current bedding

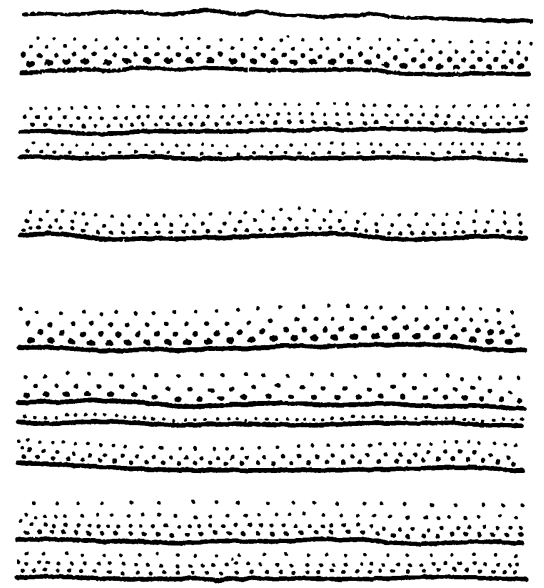

Graded bedding

図 20 Bailey の基本堆積構造（Bailey, 1936).

曲地帯の研究 (Bailey, 1910, 1914) とスコットラン ド西部の Mull 島に招ける第三紀火成岩類の岩脈群 を中心之する火山活動史の解明であった（Bailey, 1912,1945)。とくに後者に対して，1920年にイギリ 又地質調查所所長に就任した Sir John Flettは Baileyの業績を「イギリス地質学の最も輝ける成 果」と最高の言葉で評洒している (Flett, 1937).さ らに, 彼の顕著な業績は大ブリテン島全域をカバー する二枚の着色地質図（縮尺 1/625,000 初版 1947 年, 第 2 版 1957 年, 改版 1964 年) を完成したこと である. 彼の地質学への貢献はまさにイギリス地質 学の伝統である “Go and See” を不変不易のあのに したといえよう。

Bailey の魅力は成果の発表に当って, 適切な術語 が無いときは躊踷無く新語を鋳造したことである。 現在よく使われる「次第に若くなる」という意味の “to young”, “younging”などは彼の造語であった (Bailey, 1934). その他, antiformt, synform など がある (Bailey and McCallien, 1937).

ところが, 彼の研究生活は第一次世界大戦の勃発 で中断された。 1915 年に召集を受けたBaileyは 1918 年ドイツが戦争で初めて使った戦車によって 片目を失い，腕にも重傷を負うという悲劇を被っ た。しかし，1918 年に陸車中尉として退役すると， このような逆境にもめげず 1924 年には地質調査に 復帰して，ますます活発な活動を再開した。

次に Baileyの多彩な生き様に焦点を当てよう. なお，この記述には Stubblefield（1965 a, b), MacGregor（1970）, 岡田（1968）などの Bailey 伝
記を参考にした。

Bailey は 1881 年 7 月 1 日開業医であった John Battersbyと農家の娘であったBailey Louise Florence Carr の間に 6 人兄弟の三男としてロンド ン東南のケント州 Kentish Weald 地方の Marden で生まれた。幼時には父の仕事の関係で引越しが多 く, 転校も多かったが, 最後はイングランド北部の Kendal Grammar School を卒業，1898 年に奨学金 を得て Cambridge 大学 Clare College に入学した. 在学中は各種スポーツに熱中したが，勉強の方もよ く頑張り, 2 年次の自然科学優等試験 (Natural Sciences Tripos）では最優秀になっている。 とくに注 目したいことは，在学中にEduard Suess（18851909）の名作 “Das Antlitz der Erde” に強い影響を 受けて，自信満々の体力之創造力豊かな思考能力を 生かした地質学の研究に関心を強めていった. Bailey 3 年次の Tripos で地質学々物理学で首席 となり，1902 年には最優秀賞の Harkness 賞を受け た. 彼は卒業後の就職先を地質調査所にすると心に 決めていたので，希望通り，その年の 6 月に地質調 查所スコットランド支所に採用されたのは大満足 だった。

Baileyにとって地質学の桃源郷として運命づけ られることになるスコットランドの西部高地で野外 地質調査が始まった，それは彼の天職となり，その 後の成果は冒頭で紹介したとおりである。しかし， この栄光の仕事を 1929 に離れることになった。そ れはグラスゴー大学地質学科の主任教授のポストを 得たからである。 
1929 年から 1937 年まで，グラスゴー大学では学 問上の自由を享受した. とくに，この時期に堆積作 用とテクトニクスに関する二つの重要論文を発表す ることができた（Bailey, 1930, 1936).

ところが，1937 年 4 月，所長職の空席が続いてい た地質調査所から所長職への就任を要請され, 研究 時間を貪えることと, 職務管理は副所長に補佐して あらうことを条件にこの要請を受けることにした。 ところが，間もなく第二次世界大戦を迎え，所長の 仕事は国家の戦争遂行に必要な資源確保に切り替え られ，地図類・標本類のロンドンからの疎開など, 全て戦時体制への責任をとらなければならなかっ た. 唯一，1943 年に組織された地質図作成のための British Association 小委員会の業務が楽しみだっ た.

1945 年 4 月 14 日地質調查所を停年退職し，エジ ンバラに引退した. そこでは W.J. McCallien の協 力を得て研究を再開した。 その中でも, 二人のトル コ旅行の成果としてまとめたアンカラ複合岩体とア ナトリア衝上構造は蛇紋岩を含む地向斜堆積物であ り, “Steinmann trinity”と呼ばれるべきと主張し て大きい注目を引いた。“Steinmann trinity”とい う用語も Bailey の造語によるもので（Bailey and McCallien, 1953), Steinmann (1905，1926) が注目 した地向斜の中心部を特徵づける蛇紋岩・枕状溶 岩・放散虫チャートの構成を指す.

1956 年夫人 Alice Meason に先立たれた Bailey は建築家の息子 Douglas の住むロンドンに移住し た. 1914 年に結婚した夫人との間には 1 男 1 女をむ うけていた。ロンドンでは主として巨匠と呼ばれる 地質家たちの伝記執筆を楽しみに生活をしていた (Bailey, 1950, 1959, 1962). 1962 年 12 月 Bailey は Mary M.W. Young と再婚したが, 1965 年 3 月 19 日ロンドンで他界した。享年 83 歳であった。

Bailey は地質学への卓抜した貢献に対して数々 の賞牌・表彰を受けた. 1930 年に英国学士院会員 (FRS), 1943 年に学士院賞 (Royal Medal), 1945 年には同副院長に就任. エジンバラ学士院 (Royal Society of Edinburgh) から 1920 年に Neil Prize, ロンドン地質学会から Bigsby Medal (1923), Murchison Medal (1935), Wollaston Medal (1948), エジンバラ地質学会から Clough Medal （1962）に輝いた.イギリス地質調査所・博物館退官 に際し 1945 年にナイト (Knight Bachelor) に列せ られた. さらに, Harvard (1936), Birmingham
(1939), Glasgow (1946), Belfast (1946), Cambridge (1952), Edinburgh (1964) の各大学加ら名 誉学位を受けた。また, Norwegian Academy of Science \& Letters (1938), National Institute of Science of India (1941), National Academy of Sciences, Washington (1944), Royal Academy of Belgium (1946), Swiss Academy of Sciences （1948）の名誉会員に推挙された. 兵役時代には戦功 十字章, フランス勲功十字章, レジョン・ド・ヌー ル勲章を授けられた。

本稿を草するに当り, 多年 Sir Bailey を補佐し, 1960-1966 年にはイギリス地質調査所所長を勤めた 故 Sir C.J. Stubblefieldには貴重な自著の Bailey 追悼文の提供を受けた。深く感謝の意を表したい.

\section{主な業績 :}

Bailey, E.B., 1910 : Recumbent folds in the schists of the Scottish Highlands. Quart. J. Geol. Soc. London, 66, 586-618.

Bailey, E.B., 1911: A new vulcanology. Geol. Mag., Decade 5, 8, 268-273, 311-316.

Bailey, E.B., $1912 \mathrm{a}$ : The New Mountain of the year 1910, Usu-San, Japan. Geol. Mag., Decade 5, 9, 248-252.

Bailey, E. B., 1912 b : A Mull problem : the great Tertiary breccia. Geol. Mag., Decade 5, 9, 517.

Bailey, E. B., 1914 : The Balachulish fold near the head of Loch Creran. Quart. J. Geol. Soc. London, 70, 321-327.

Bailey, E. B., 1924 : The desert shores of the chalk seas. Geol. Mag., 61, 102-116.

Bailey, E.B., 1926a : Plant migration across the Millstone Grit. Geol. Mag., 63, 49-61.

Bailey, E. B., 1926b : Subterranean penetration by a desert climate. Geol. Mag., 63, 276-280.

Bailey, E.B., 1928 : James Hutton : the father of modern geology, 1726-1797. Trans. Edin. Geol. Soc., 12, 183-186.

Bailey, E. B., Collet, L. W. and Field, R. W., 1928 : Palaeozoic submarine landslips near Quebec City. J. Geol., 26, 577-614.

Bailey, E.B., 1930 : New light on sedimentation and tectonics. Geol. Mag., 78, 77-92.

Bailey, E. B. and Weir, J., 1932 : Submarine faulting Kimmeridgian times: East Scotland. Trans. Roy. Soc. Edinburgh, 57, 429-467. 
Bailey, E.B., 1934 : West Highland tectonics : Loch Leven to Glen Roy. Quart. J. Geol. Soc. London, 90, 462-525.

Bailey, E. B., 1936 : Sedimentation in relation to tectonics. Bull. Geol. Soc. Am.., 47, 1713-1725.

Bailey, E.B. and McCallien, W.J., 1937 : Perthshire tectonics: Schiehallion to Glen Lyon. Trans. Roy. Soc. Edinburgh, 59, 79-117. Bailey, E.B., 1940 : Submarine canyons. Nature, 146, 493.

Bailey, E. B., 1945 : Tertiary igneous tectonics of Rhum (Inner Hebrides). Quart. J. Geol. Soc. London, 100, 165-191.

Bailey, E.B., 1950 : James Hutton founder of modern geology, 1726-1797. Proc. Roy. Soc. Edinburgh, 63, 357-368.

Bailey, E. B. and McCallien, W.J., 1953 : Serpentine lavas, the Ankara mélange and the Anatolian thrust. Trans. Roy. Soc. Edinburgh, 62, 403-442.

Bailey, E.B., 1959 : Charles Lyell, F.R.S. (17971875). Not. Rec. Roy. Soc., 14, 121-138.

Bailey, E. B. and McCallien, W.J., 1960 : Some aspects of the Steinmann trinity, mainly chemical. Quart. J. Geol. Soc. London, 116, 365-395.

Bailey, E. B., 1962 : Charles Lyell. Nelson \& Sons, London.

\section{Philip Henry Kuenen (1902-1976)}

Thomas S. Kuhn（1962）の科学は漸進的に進歩 するのではなく爆発的に発展するという有名な科学 革命論（scientific revolution）はパラダイム科学 観と呼ばれている(都城, 1998). タービダイトの研 究で優れた貢献を果たしたカナダの R.G. Walker (1973) は Ph. H. Kuenen こそ科学に革命を起こし た科学者であるとして Kuenenの功績を “the turbidity current revolution”之呼んで評価した。 ま さにその通りである.

Philip Henry Kuenen（フィリップ・ヘンリー・ キューネン) (図 21) はE.B. Bailey（上述）が 1930 年に提唱した級化層理 (graded bedding) の成因に 深い関心を抱いていた。すずに地質現象としての密 度流の存在を示唆したR.A. Daly（1936）や, 密度 流よりあ高密度の流れとして混濁流（turbidity

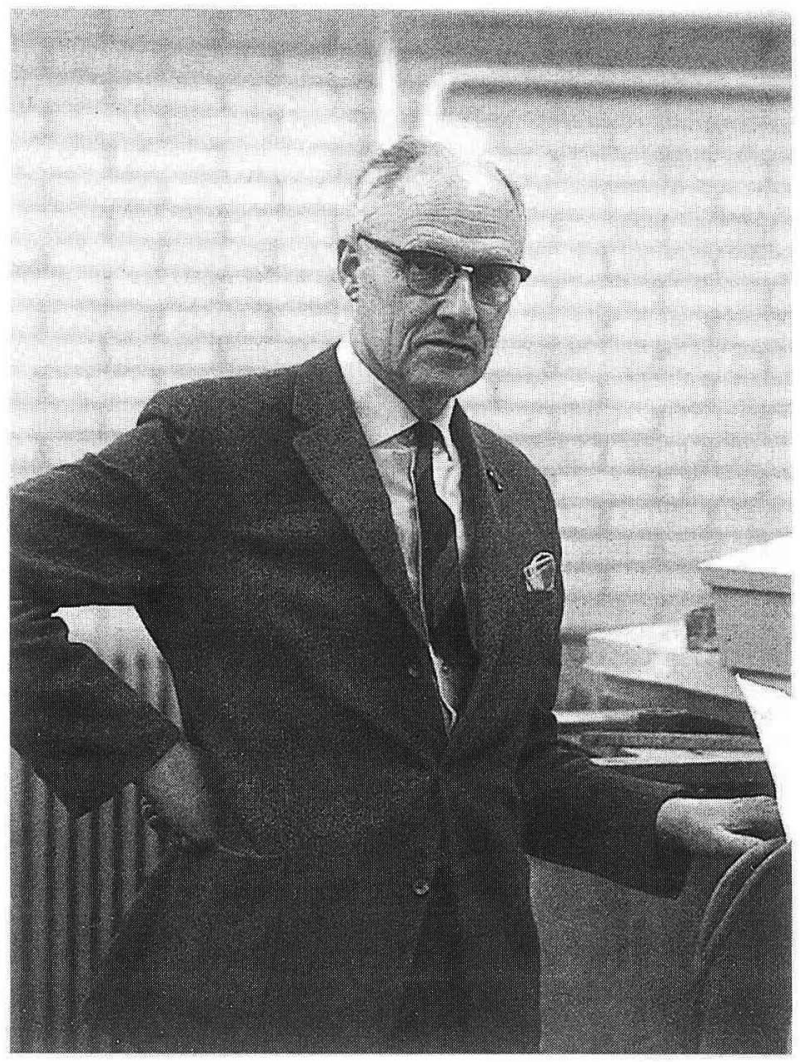

図 21 Philip Henry Kuenen (1965 年, 最初の混 濁流実験で使った水槽の横で著者撮影).

current）という用語が D.W. Johnson（1939）に よって提唱されていたが, それらの挙動の実態を実 験で確かめようとしたのはKuenen (1937) であっ た. 彼は先ず大きい刺激を受けた Daly（1936）の海 底峡谷の侵食は密度流の働きによるという密度流を 実験で確かめることにし, Daly 説の正当性を確認 した (Kuenen, 1937). まむなく Johnson (1939) は 水温や塩分濃度による高密度の流れを密度流と区別 するため混濁流の概念を提唱したが，これ屯実験で 確証した (Kuenen, 1948, 1950 a).これらの成果を 基に Kuenen の名著 “Marine Geology” の中ではす でに混濁流は深海に砂を運び，級化層理を作るこ と, さらに海底峡谷の侵食にも関係していることを 明確に述べている（Kuenen, 1950 b, The cause of graded bedding, pp. 366-367; Turbidity Currents, pp. 509-526). そして，実験に基づく密度流 や混濁流に関する彼の信念はKuenen and Migliorini (1950) の論文で完成した. 当時 Kuenen はイ タリアの北部アペニン山脈マチーニョ（Macigno） 
地域の漸新世フリッシュ級化堆積層を研究していた フィレンツェ大学教授の C. I. Migliorini と協力し て野外での地質学的資料を確認しながら混濁流の実 験に力を入れていた。 なお, 日本語の混濁流は最初 乱泥流と呼ばれていた。

その後の混濁流の研究はその堆積物であるタービ ダイトの研究と共に地質学, 堆積学の主流となって 大発展を遂げて現在に至っている. Kuenen 自信の 混濁流・タービダイト研究のその後の展開は Kuenen（1964）の中で要約されている.

このようにKuenen は地質学研究に実験の重要 性を訴え (Kuenen, 1958a, 1965), 当然堆積学研究 にむ実験を取り入れたものが多かった（Kuenen, 1956 b, 1959 b, 1960, 1963, 1964a). 例えば, 砂火山 (sand volcano), 荷重痕 (load cast), 偽磁 (pseudo-nodule) などの堆積構造の生成過程や砕屑粒子 の摩耗実験などは代表的な研究であった。

次に Kuenen の生い立ちを van Straaten (1977), Küppers・鈴木 (1987), Middleton（2003）などの 資料を基に見ておこう。

Philip Henry Kuenen は 1902 年 7 月 2 日スコッ トランドのエジンバラの北, ダンディー (Dundee) の町で生まれた。父はオランダ出身の物理学者で, 母はイギリス人であった. 1907 年両親と共にオラン ダのライデン (Leiden) に移住した。 そこでは石に 興味を引かれるようになり，8歳の頃から石集めを 始め, 地質学に関心を持つようになったという。彼 はこの地で教育を受け, 最後はライデン大学で地質 学を専攻した. 構造地質学で著名な J. H.F. Umbgroveや L.U. de Sitter はそのときの同級生だった という. 大学では 1922-1925 年のイタリア北部の地 質学的・岩石学的研究で学位を取得, 直ちに 1925 26 年の空軍軍務に服した.

1926 年に兵役を離れると, 1934 年までライデン 大学の助手を勤めた. このとき, 学位論文の指導教 官であった B.G. Escher (エスハー) 教授の推薦で 1929-1930 年のスネリウス号 (Snellius) 海洋調査に geologist として参加することになった. Kuenen の名著 “Marine Geology” の冒頭には Escher 教授 に“Inspiring teacher” と感謝を捧げている.イン ドネシア東部海域を中心としたスネリウス号での海 洋調査はKuenen を海洋地質学にも取り込み, 彼の 研究人生に極めて大きい影響を与え, “No geology without marine geology”という名言を遺したほ よ゙である (Kuenen, 1958 b).
1934 年 Kuenen はフローニンゲン (Groningen) 大学の講師に採用された。この大学では地質学が軽 視され，1932 年に地質学教室は廃止されていた。し かし, 当時ナチス・ドイッに占領されていたオラン ダで, 1943 年にライデン大学が閉鎖されると, 学生 たちはフローニンゲン大学の Kuenenの周りに集 まってきた。しかし，ナチス・ドイッはそれを禁じ てしまった. 1943 年に正教授に昇格, 1946 年にはフ ローニンゲン大学に地質学教室が復活した (図 22). そして，修士コースもできたが，博士コースは作ら れなかったという。このように教育環境は惠まれな かったが，彼自信は教育には余り熱心ではなかっ た. 1966 年までの地質学教室の学生数はたったの 3 人だったという。その中にあの有名な A.H. Bouma がいた. 当時のフローニンゲン大学には Kuenen の 他に潮間带堆積作用研究の巨匠L. M. J. U. van Straaten がいて, ヨーロッパ堆積学の中心の感が あった。

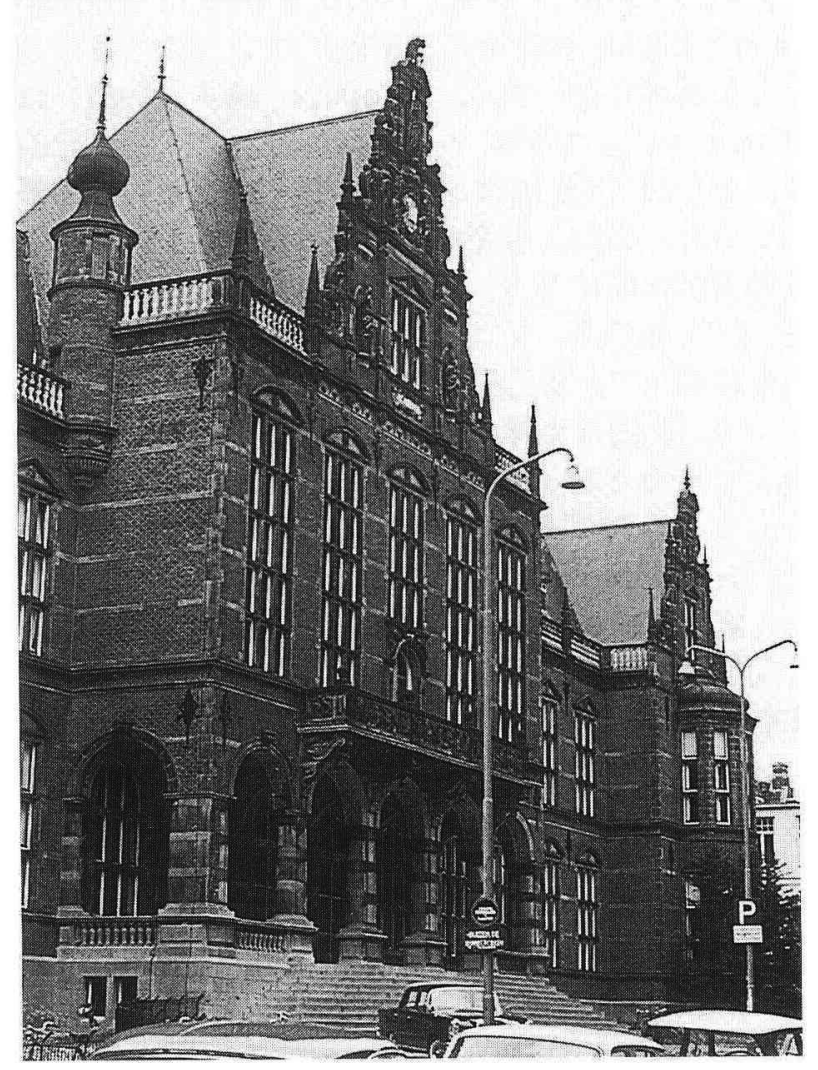

図 22 Groningen 大学 (1965 年著者撮影). 
Kuenen の晚年は悲惨であった. 1967 年に夫人が 逝去された後，1970年にはKuenen を委員の一人 とする大学側の強い反対運動にも拘らずオランダ政 府によるフローニンゲン大学地質学教室の廃止が決 まるなど，Kuenenの精神的ストレスは急速に増大 し, 神経衰弱の症状がでてきた。こうしたなかで, 1972 年に大学を停年退職. 1976 年には Naardenの 養老院に入った。しかし, 神経衰弱は回復すること なく，1976 年 12 月 17 日，ライデンの病院で動脈瘤 のために永眠した。享年 74 歳であった。

Kuenenの業績に対して，彼は次のような数々の 顕彰を受けている. Dumont, Water-schoot, Van der Gracht, Penrose, Steinmann, Wollaston, Shepard Medals, さらにオランダ政府からライオン 勲章を授与され，騎士に列せられた。 また，オラン ダ王立科学アカデミー会員, ベルギー, イギリス, スウェーデン, アメリカ各地質学会の名誉会員, ア メリカ芸術科学アカデミー会員, ニューヨーク科学 アカデミー会員などに推挙された. Dublin, Exter, Krakauなどの各大学からは名誉博士号を授与され ている.

F.J. Pettijohn（1984）は Kuenenを “an imaginative, highly original thinker” で，完璧な英語を 話したと評した。また，Küppers・鈴木（1987）は 「Kuenen はイマジネーションが豊かで, 三次元的 な，また四次元的なイメージを描くのにたいへん優 れていた。また，手先が器用だったことああって実 験地質学に興味をむった」と彼を評している．著者 屯, 1965 年の春, フローニンゲン大学で眼光鋭く, 自信に満ちて, 端正な風格を備えた Kuenen に会っ た. 未だ脆弱な東洋の一学徒に優しく接してくれた のが印象的であった．そのとき，日本では混濁流説 をどのように評価しているかを，大变気にしてい た. G.V. Middleton (2003) は Kuenen は確かに優 れた実験家であったが，数学または数理理論の知識 に問題があったと評している.

\section{主な業績 :}

Kuenen, Ph. H., 1937 : Experiments in connection with Daly's hypothesis on the formation of submarine canyons. Leidse Geol. Mededel., 8, 327-335.

Kuenen, Ph. H., 1948 : Slumping in the Carboniferous rocks of Pembrokeshire. Quart. J. Geol. Soc. London, 104, 365-385.

Kuenen, Ph. H., 1950 a : Turbidity currents of high density. $18^{\text {th }}$ Intern. Geol. Congr., London, 1948, Rept., Pt. 8, 44-52.

Kuenen, Ph. H., 1950 b : Marine Geology. Wiley, New York, $568 \mathrm{p}$.

Kuenen, Ph. H. and Migliorini, C. I., 1950 : Turbidity currents as a cause of graded bedding. $J$. Geol., 58, 91-127.

Kuenen, Ph. H., 1952 : Estimated size of the Grand Banks turbidity current. Am. J. Sci., 250, 874-884.

Kuenen, Ph. H. and Menard, H.W., 1952 : Turbidity currents, graded and non-graded deposits. J. Sediment. Petrol., 22, 83-96.

Kuenen, Ph. H., 1953 a : Origin and classification of submarine canyons. Bull. Geol. Soc. Am., 64, 1295-1314.

Kuenen, Ph. H., $1953 \mathrm{~b}$ : Significant features of graded bedding. Bull. Am. Assoc. Petrol. Geol., 37, 1044-1066.

Kuenen, Ph. H., 1956 a : The difference between sliding and turbidity flow. Deep-Sea Res., 3, 134-139.

Kuenen, Ph. H., 1956 b : Experimental abrasion of pebbles : 2. Rolling by current. J. Geol., 64, 336-368.

Kuenen, Ph. H., 1957 : Sole markings of graded greywacke beds. J. Geol., 65, 231-258.

Kuenen, Ph. H. and Gill, D., 1957 : Sand volcanoes on slumps in the Carboniferous of County Clare, Ireland. Quart. J. Geol. Soc. London, 113, 441-160.

Kuenen, Ph. H. and Prentice, J.E., 1957 : Flow markings and load-casts. Geol. Mag., 94, 173174.

Kuenen, Ph. H., 1958 a : Experiments in geology. Trans. Geol. Soc. Glasgow, 23, 1-9.

Kuenen, Ph. H., 1958 b : No geology without marine geology. Geol. Rundschau, 47, 1-10.

Kuenen, Ph. H., 1959 a : Turbidity currents a major factor in flysch deposition. Eclogae Geol. Helv., 51, 1009-1021.

Kuenen, Ph. H., $1959 \mathrm{~b}$ : Experimental abrasion, pt. 3 : Fluviatile action on sand. Am. J. Sci., 257, 173-190.

Kuenen, Ph. H., 1960 : Experimental abrasion, pt. 
4 : Eolian action. J. Geol., 68, 427-449.

Kuenen, Ph. H., 1963 : Pivotability studies of sand by a shape-sorter. Sedimentology, 1, 208-215.

Kuenen, Ph. H., 1964 a : Experimental abrasion, pt. 6 : Surf action. Sedimentology, 3, 29-43.

Kuenen, Ph. H., $1964 \mathrm{~b}$ : Deep sea sands and ancient turbidites. In : Bouma, A.H. and Brouwer, A. (eds.) : Turbidites. Elsevier, Amsterdam, 3-33.

Kuenen, Ph. H., 1965 : Value of experiments in geology. Geol. Mijnbouw, 44, 22-36.

\section{文献}

Daly, R. A., 1936 : Origin of submarine "canyons". Am. J. Sci., 31, 401-420.

Flett, J.S., 1937 : The First Hundred Years of the Geological Survey of Great Britain. HMSO.

Johnson, D. W., 1939 : The Origin of Submarine Canyons. A Critical Review of Hypotheses. Columbia Univ. Press, New York, $126 \mathrm{p}$.

Kuhn, T.S., 1962: The Structure of Scientific Revolutions. Univ. Chicago Press, Chicago, 277 p.

Küppers, A.N.・鈴木尉元， 1987 : キューネンの生涯と業績. 地 質ニュース，(396)，26-29.

MacGregor, A G., 1970 : Bailey, Edward Battersby. In : Gillispie, C.C. (ed.) : Dictionary of Scientific Biography. Vol. 1. Charles Scribner's Sons, New York, 393-395.

Middleton, G. V., 2003 : Philip Henry Kuenen (1902-1976). In :
Middleton, G. V. (ed.) : Encylopedia of Sediments and Sedimentary Rocks. Kluwer Academic Publishers, Dordrecht, The Netherlands, 646-647.

都城秋穂, 1998 : 科学革命之は何か. 岩波書店, $x v+331+16$ p. 岡田博有，1968：あるジオロジストの歩いた道 (1)，(2)．Edward Battersby Bailey 1881-1965. 地質ニュース，(171)，58-63； (172), 49-53.

岡田博有, 2002 : 堆積学一新しい地球科学の成立一. 古今書院, xiii +219 p.

Pettijohn, F.J., 1984 : Memoirs of an Unrepentant Field Geologist. Univ. Chicago Press, Chicago, ix $+260 \mathrm{p}$.

Steinmann, G., 1905 : Die geologische bedeutung der Tiefseeabs?tze und der ophiolitischen Massengestein. Naturf. Gesell. Freiberg Ber., 16, 44-65.

Steinmann, G., 1926 : Die ophiolitischen Zonen in dem mediterranen Kettengebirge. Congr. Géol. Intern., Compt. Rend., 14e, Madrid, 1926, 2, 636-638.

Stubblefield, C.J., 1965 a : Edward Battersby Bailey 18811965. Biographical Memomirs of Fellows of the Royal Society, 11, 1-21.

Stubblefield, C.J., 1965 b : Sir Edward Bailey, M.C., F.R.S. Nature, 207 (4996), 464-465.

Suess, E., 1885-1909: Das Antlitz der Erde. 3 vols. Tempsky, Vienna.

van Straaten, L.M.J. U., 1977 : In memoriam Ph. H. Kuenen. Geol. Mijnbouw, 56 (1), 1-3.

Walker, R.G., 1973 : Mopping up the turbidite mess. In : Ginsburg, R.N. (ed.) : Evolving Concepts in Sedimentology. Johns Hopkins Univ. Press, Baltimore, 1-37. 